\title{
ANALISIS EFISIENSI TEKNIS PRODUKSI UBI KAYU DI PROVINSI LAMPUNG TAHUN 2017: PENDEKATAN STOCHASTIC FRONTIER ANAL YSIS
}

\author{
( Technical Efficiency Analysis of Cassava Production in Lampung Province 2017: \\ Stochastic Frontier Analysis Approach)
}

\author{
Ainun Mardhiah ${ }^{1}$, Atik Mar'atis Suhartini ${ }^{2}$ \\ Politeknik Statistika STIS ${ }^{1}$ Politeknik Statistika STIS² \\ Jalan Otto Iskandardinata Nomor 64C Jakarta 13330 E-mail: $\underline{15.8480 @ s t i s . a c . i d ~}$
}

\begin{abstract}
ABSTRAK
Ketahanan pangan merupakan salah satu permasalahan pembangunan di Indonesia. Salah satu cara mengatasinya yaitu diversifikasi pangan dengan ubi kayu sebagai salah satu pengganti beras. Akan tetapi, Provinsi Lampung sebagai provinsi dengan produksi ubi kayu paling tinggi di Indonesia mengalami penurunan produksi. Solusi yang dapat dilakukan adalah intensifikasi dengan cara meningkatkan produktivitasnya salah satunya peningkatan efisiensi teknis. Penelitian ini bertujuan untuk menganalisa efisiensi teknis produksi ubi kayu dan variabel yang memengaruhi inefisiensi teknisnya di Provinsi Lampung dengan menggunakan raw data Survei Struktur Ongkos Usaha Tani (SOUT) Palawija 2017. Hasil analisis dengan metode Stochastic Frontier Analysis (SFA) menunjukkan bahwa Provinsi Lampung memiliki efisiensi teknis sedang. Variabel yang berpengaruh signifikan terhadap inefsiensi produksi ubi kayu di Provinsi Lampung adalah jenis kelamin petani, usia, tingkat pendidikan, keikutsertaan penyuluhan, dan kelompok tani. Perbaikan dari sisi pengetahuan dan keterampilan petani dalam meningkatkan produktivitasnya lebih diutamakan untuk petani berjenis kelamin laki-laki, berusia muda, dan berpendidikan rendah.
\end{abstract}

Kata kunci: produksi ubi kayu, efisiensi teknis, stochastic frontier analysis (SFA)

\section{ABSTRACT}

Food security is one of the development problems in Indonesia. One way to overcome this problem is by diversifying with cassava as rice substitute. However, Lampung as the province with highest cassava production got a decline in it's production. The solution can be done is intensification by improving productivity through increasing technicalefficiency. This studyaims to analyze technicalefficiency of cassava production and variables that affect its technical inefficiencies in Lampung Province using raw data of farm cost structure survey 2017. The results by the Stochastic Frontier Analysis (SFA) method shows that Lampung Province has moderate technical efficiency. Sex of the farmer, age, education level, participation in counseling, and farmer groups are variables that significantly influence the ineffeciency production of cassava. Improvements of knowledge and farmer skills that increase their productivity are prioritized for farmers of male sex, young age, and low education.

Keywords: cassava production, technical efficiency, stochastic frontier analysis (SFA)

\section{PENDAHULUAN}

\section{Latar Belakang}

Pangan merupakan kebutuhan dasar manusia yang paling utama dimana pemenuhannya ditujukan untuk menentukan kualitas sumber daya manusia. Selain itu, pemenuhan kebutuhan pangan merupakan hal yang penting karena kurangnya bahan pangan di suatu negara akan mengancam stabilitas negara baik dari sisi ekonomi maupun sosial. Masalah pemenuhan kebutuhan pangan ini juga tidak luput dari perhatian dunia yang tertuang dalam salah satu tujuan Sustainable Development Goal's (SDG's) yaitu tanpa kelaparan dengan salah satu rincian tujuan yaitu mencapai ketahanan pangan.

Pencapaian ketahanan pangan masih menjadi tantangan di negara-negara maju maupun berkembang. Menurut Nainggolan (2009) tantangan tersebut diantaranya adalah semakin meningkatnya jumlah penduduk, menciutnya populasi petani, kenaikan harga bahan bakar minyak, 
dan perubahan iklim. Berdasarkan Indeks Ketahanan Pangan Global atau Global Food Security Index (GFSI) tahun 2017, Indonesia menempati peringkat 109 dari 113 negara pada kategori Natural Resources \& Resillence dimana kategori ini menilai dampak dari perubahan iklim terhadap ketahanan sumber daya alam. Kondisi ketahanan pangan Indonesia dalam menghadapi perubahan iklim tahun 2017 (indeks 46,5) pun masih jauh berada di bawah negara-negara tetangga, seperti Myanmar (indeks 69,5), Thailand (indeks 64,30), Kamboja (indeks 63,8), Vietnam (indeks 58,1), Malaysia (indeks 52,1). Fakta tersebut menunjukkan masih terdapat ancaman ketahanan pangan apabila terjadi perubahan iklim di Indonesia.

Strategi kebijakan yang dapat menyelesaikan permasalahan pangan adalah melalui swasembada pangan. Walaupun pada tahun 1984 dan 2008 Indoensia telah mencapai swasembada beras namun kenyataannya sampai saat ini Indonesia masih membutuhkan impor beras dari negara lain untuk memenuhi kebutuhan konsumsi nasional. Artinya bahwa swasembada pangan beras yang telah tercapai sejauh ini hanya bersifat sementara dan tidak berkelanjutan (BPS, 2015). Studi yang dilakukan Astuti (2011) menyebutkan bahwa impor beras ini dapat ditekan dengan melakukan diversifikasi pangan. Berdasarkan Undang-Undang Nomor 18 Tahun 2012 tentang Pangan ditegaskan bahwa diversifikasi pangan adalah upaya penigkatan ketersediaan dan konsumsi pangan yang beragam, bergizi seimbang, dan berbasis pada potensi sumber daya lokal.

Berdasarkan hasil Survei Sosial Ekonomi Nasional (Susenas) Maret 2017 rumah tangga yang mengonsumsi ubi kayu meningkat 11,27 persen dimana peningkatan ini merupakan peningkatan partisipasi konsumsi rumah tangga tertinggi apabila dibandingkan dengan komoditas bahan karbohidrat lainnya seperti jagung basah ( $-9,79$ persen), ketela rambat (1,98 persen), dan talas (2,06 persen). Hal ini menunjukkan bahwa ubi kayu merupakan sumber karbohidrat yang cukup digemari disamping beras.

Menurut Kementerian Pertanian (2016) ubi kayu memiliki peranan yang cukup penting dalam menopang ketahanan pangan suatu wilayah. Hal itu dikarenakan ubi kayu mempunyai beberapa keunggulan dibandingkan tanaman pangan lain, diantaranya dapat tumbuh di lahan kering dan kurang subur, daya tahan terhadap penyakit relatif tinggi, masa panennya tidak diburu waktu sehingga dapat dijadikan lumbung hidup, serta daunnya dan umbi ubi kayu dapat diolah menjadi aneka makanan, baik makanan utama maupun selingan (Syafina, 2014). Pentingnya komoditas ubi kayu ini tertuang dalam Rencana Strategis Kementerian Pertanian Tahun 2015-2019 dimana salah tujuan pembangunan pertanian sub sektor tanaman pangan adalah meningkatkan kapasitas dan mutu produksi ubi kayu (Kementerian Pertanian, 2015). Oleh karena itu produksi ubi kayu merupakan hal yang harus diperhatikan mengingat pentingnya ubi kayu dalam mewujudkan ketahanan pangan sekaligus sebagai sumber karbohidrat pengganti beras.

\section{Rumusan Masalah}

Pentingnya ubi kayu sebagai salah satu pengganti beras yang potensial serta peningkatan rumah tangga yang mengkonsumsinya, seharusnya diikuti peningkatan produksinya. diversifikasi pangan melalui tanaman Namun, produksi ubi kayu di Indonesia cenderung mengalami penurunan dari tahun 2010 hingga 2017. Bahkan pada tahun 2017 penurunan produksi ini jelas terlihat pada provinsi Lampung yang merupakan penghasil ubi kayu terbesar di Indonesia. Penurunan pada tahun tersebut sebesar 14,50 persen dimana penurunan ini yang paling tajam dibandingkan dengan penurunan pada tahun-tahun sebelumnya. Menurut BPS (2015) peningkatan produksi dengan pertambahan luas lahan atau areal luas tanam (ekstensifikasi) sangat sulit diupayakan. Jumlah penduduk yang terus meningkat berdampak pada kompetisi penggunaan lahan yang semakin ketat. Selain itu, Rumapea (2017) juga menyebutkan bahwa diperlukan biaya yang besar dalam pembukaan lahan baru. Oleh karena itu, peningkatan produktivitas melalui upaya intensifikasi merupakan alternatif solusi. Intensifikasi dalam produksi ubi kayu menitikberatkan pada peningkatan kualitas dan kuantitas serta produktivitas per hektar (Kementerian Pertanian, 2016). Peningkatan produktivitas dapat dilakukan dengan cara meningkatakan efisiensi teknis. 


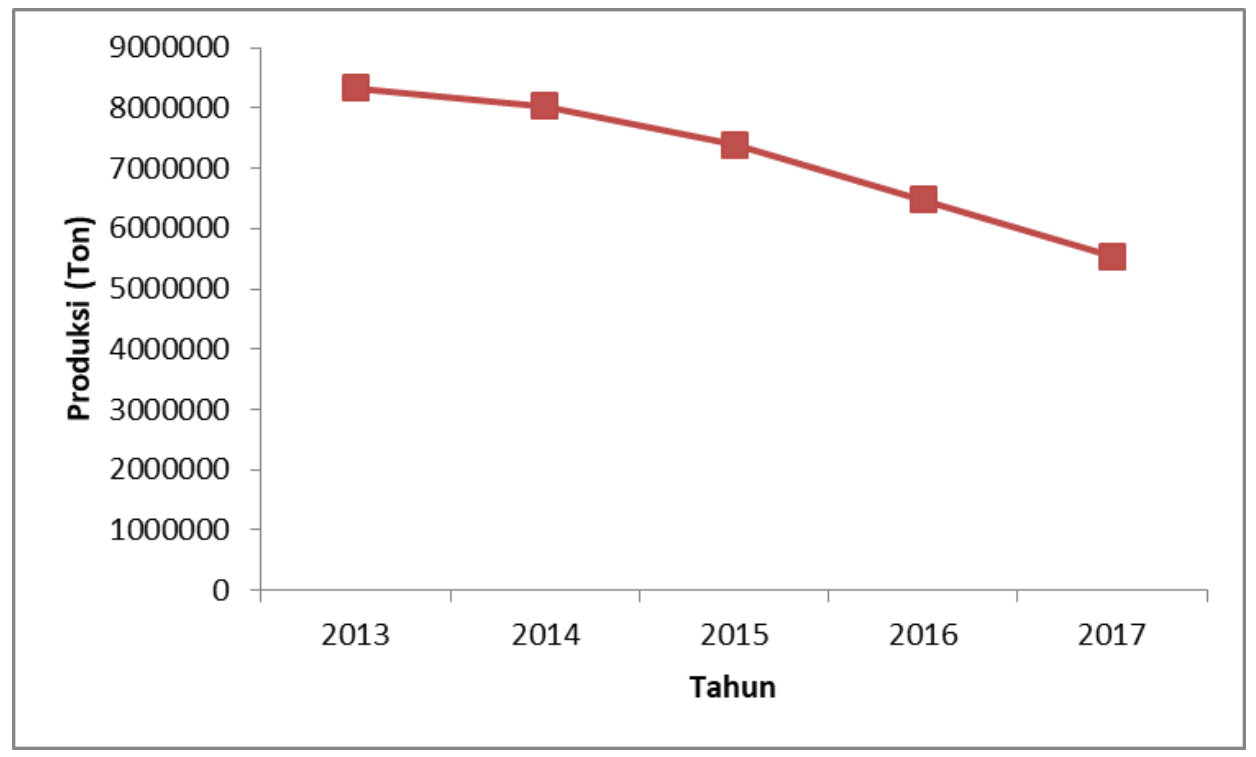

Gambar 1. Produksi Ubi Kayu Provinsi Lampung Tahun 2013-2017

\section{Tujuan Penelitian}

Berdasarkan uraian latar belakag serta perumusan masalah maka tujuan penelitian ini diantaranya adalah menganalisis efisiensi teknis di Provinsi Lampung beserta variabel karakteristik petani yang mempengaruhi inefsiensi teknis produksinya. Inefisiensi teknis yang dimaksud adalah hal-hal yang tidak secara langsung mengurangi efisiensi proses produksi ubi kayu, seperti halnya pengetahuan petani yang kurang dalam proses produksi ubi kayu yang baik, akses pendanaan dari petani yang kurang sehingga kurang mendukung dalam proses produksi ubi kayu dan lainnya. Hasil analisisnya dapat digunakan untuk dasar pengambilan kebijakan terkait peningkatan produksi ubi kayu melalui peningkatan efisiensi produksinya di Provinsi Lampung.

\section{METODE}

Penelitian ini dilakukan untuk menganalisis efisiensi teknis produksi ubi kayu tahun 2017 di Provinsi Lampung. Efisiensi teknis diperoleh dari rasio output yang dihasilkan oleh petani ubi kayu dengan output ketika petani dalam kondisi efisien penuh (dihitung berdasarkan persamaan fungsi produksi Cobb Douglass). Kondisi petani efisien penuh berarti semua input terolah secara optimal tanpa ada sisa yang terbuang. Output produksi ketika petani dalam kondisi efisien penuh menggunakan variabel dependen produksi ubi kayu dan variabel independen luas panen, tenaga kerja, jumlah bibit, dan pupuk urea. Sementara untuk mencari variabel apa saja yang berpengaruh signifikan terhadap inefsiensi teknis, variabel dependen yang digunakan adalah efek inefisiensi teknis sedangkan variabel independennya antara lain usia, pendidikan, jenis kelamin, jumlah anggota rumah tangga, keanggotaan kelompok tani, keikutsertaan penyuluhan usaha tani, dan status kepemilikan lahan petani ubi kayu. Penelitian ini menggunakan raw data dari Survei Struktur Ongkos Usaha Tani (SOUT) Palawija 2017 yang dilaksanakan oleh Badan Pusat Statistik (BPS).

Fried, Lovell, dan Schmidt (2008) menjelaskan efisiensi teknis merupakan kemampuan menghasilkan output sebanyak mungkin dari input tertentu atau dengan menghasilkan output dengan teknologi dan penggunaan input sedikit mungkin. Dalam penghitungan efisiensi teknis terdapat dua model yang dapat digunakan yaitu model parametrik dan nonparamterik. Namun, model nonparamterik memiliki keterbatasan yaitu tidak adanya penghitungan untuk statistical noise sehingga seluruh deviasi dari frontier diasumsikan disebabkan oleh inefsiensi teknis (Coelli, 2005). Oleh karena itu digunakan model parametrik seperti yang disebutkan Coelli (2005) yaitu Stochastic Frontier Analysis (SFA) dimana telah mengakomodasi penghitungan error yang disebabkan statistical noise dan efek inefsiensi teknis. 
SFA adalah metode parametrik yang digunakan untuk melakukan estimasi efisiensi teknis suatu unit usaha. Aigner, Lovell dan Schmidt (1977) mengajukan model fungsi produksi stochastic frontier dengan bentuk:

In qi $=x i^{\prime} \boldsymbol{B}+\mathrm{vi}-\mathrm{ui}$

dimana:

$\mathrm{i} \quad=1,2,3, \ldots, \mathrm{n}$

qi $=$ output dari unit usaha ke-i

$\boldsymbol{x i}^{\prime}=$ vektor berukuran $\mathrm{K} \times 1$ hasil logaritma input-input

$\boldsymbol{\beta}=$ vektor parameter yang tidak diketahui vi $=$ statistical noise

ui $=$ efek inefisiensi

Secara umum pengukuran efisiensi teknis dari adalah perbandingan antara output aktual dan output maksimal yang dapat dicapai yang didapatkan dari fungsi stochastic frontier.

$\mathrm{TEi}=\mathrm{qi} / \exp \left(\boldsymbol{x} \boldsymbol{i}^{\prime} \boldsymbol{\beta}+\mathrm{vi}\right)=\exp \left(\boldsymbol{x} \boldsymbol{i}^{\prime} \boldsymbol{\beta}+\mathrm{vi}-\mathrm{ui}\right) / \exp \left(\boldsymbol{x} \boldsymbol{i}^{\prime} \boldsymbol{\beta}+\mathrm{vi}\right)=\exp (-\mathrm{ui})$

Nilai dari hasil pengukuran efisiensi teknis ini berada di antara nol dan satu. Semakin mendekati nilai satu maka semakin mendekati efsiensi teknis yaitu produksi aktual yang dihasilkan dengan produksi maksimal yang dapat dicapai. Untuk menghitung efisiensi teknis menggunakan SFA, digunakan aplikasi FRONTIER 4.1 dalam penelitian ini.

Dalam melakukan estimasi efisiensi teknis beserta variabel yang mempengaruhi inefsiensi teknisnya maka model yang digunakan antaranya:

\section{Model Fungsi Produksi Cobb-Douglas}

In produksi $i_{i}=\beta_{0}+\beta_{1}$ In luas panen ${ }_{i}+\beta_{1} \ln$ bibit $_{i}+\beta_{2}$ In pupuk urea ${ }_{i}+\beta_{3} \ln$ tenaga kerja $i+\left(v_{i}-u_{i}\right)$

dimana:

$\mathrm{i} \quad=1,2,3, ., 4211$

produksi $i_{i} \quad=$ total produksi ubi kayu RTU ke-i $(\mathrm{kg})$

luas panen $\quad=$ luas panen ubi kayu RTU ke-i $\left(\mathrm{m}^{2}\right)$

bibit $_{i} \quad$ = jumlah bibit ubi kayu RTU ke-i $(\mathrm{kg})$

pupuk urea $_{\mathrm{i}} \quad=$ pupuk urea RTU ke-i $(\mathrm{kg})$

tenaga kerja $\quad=$ tenaga kerja RTU ke-i (orang)

2. Model Inefsiensi Teknis

$$
\begin{aligned}
& U_{i}=\delta_{0}+\delta_{1} A R T_{i}+\delta_{2} J_{i}+\delta_{3} U_{s i a_{i}}+\delta_{4} \text { Pendidikan }_{i}+\delta_{5} K_{\text {KepLahan }}+\delta_{6} \text { Penyuluhan }_{i}+\delta_{7} K_{\text {KlpTani }}+w_{i} \\
& \text { dimana: } \\
& \text { i } \quad=1,2,3, .4211 \\
& \mathrm{u}_{\mathrm{i}} \quad=\text { efek inefsiensi teknis rumah tangga ke-i } \\
& \mathrm{ART}_{\mathrm{i}} \quad=\text { variabel anggota rumah tangga petani ke-i (numerik) } \\
& \mathrm{JK}_{\mathrm{i}} \quad=\text { jenis kelamin petani ke-i (1=laki-laki; } 0 \text { =perempuan) } \\
& \text { Usia } \quad \text { = usia petani ke-i (numerik) } \\
& \text { Pendidikan }_{\mathrm{i}} \quad=\text { dummy pendidikan terakhir petani ke-i }(1=\text { minimal SLTP; } 0=\text { belum tamat } \\
& \text { SLTP) } \\
& \text { KepLahan }_{\mathrm{i}} \quad=\text { dummy status kepemilikan lahan petani ke-i }(1=\text { milik sendiri/bebas sewa; } 0= \\
& \text { sewa) } \\
& \text { Penyuluhan }_{\mathrm{i}} \quad=\text { dummy keikutsertaan penyuluhan usaha tani petani ke-i }(1=\mathrm{ikut} ; 0=\text { tidak ikut }) \\
& \text { KlpTani }_{\mathrm{i}} \quad=\text { dummy keanggotaan kelompok tani petani ke-i }(1=\text { anggota; } 0=\text { bukan } \\
& \text { anggota) }
\end{aligned}
$$


$\mathrm{W}_{\mathrm{i}}$ $=$ error term yang diasumsikan berdistribusi normal iid $\sim N\left(0, \sigma^{2}\right)$

Langkah-langkah dalam melakukan analisis inferensia menggunakan SFA dengan menggunakan bantuan aplikasi FRONTIER 4.1 adalah sebagai berikut:

1. Uji distribusi efek inefsiensi teknis untuk mengetahui distribusi komponan inefsiensi teknis $\left(u_{i}\right)$ apakah mengikuti sebaran half normal atau truncated normal.

2. Uji keberadaan efek inefisiensi untuk melihat apakah terdapat efek inefsiensi dalam proses produksi

3. Pengujian signifikansi parameter model fungsi produksi Cobb-Douglas untuk menentukan variabel apa saja yang berpengaruh signifikan terhadap produksi ubi kayu

4. Pengujian signifikansi parameter model inefsiensi teknis untuk mengetahui variabel apa saja yang berpengaruh signifikan terhadap efek inefisiensi teknis.

Untuk mempermudah proses analisis, efisiensi teknis dikategorikan menjadi tiga yaitu (BPS, 2015):

1. Efisiensi rendah, dengan batas efisiensi teknis kurang dari 0,5 ;

2. Efisiensi sedang, dengan batas efisiensi teknis 0,5 sampai 0,8 ;

3. Efisiensi tinggi, dengan batas efisiensi teknis lebih dari 0,8.

\section{HASIL DAN PEMBAHASAN}

Dengan menggunakan model parametrik maka data diasumsikan mengikuti suatu sebaran tertentu. Setelah dilakukan pengujian menggunakan FRONTIER 4.1 didapatkan bahwa komponen inefsiensi teknis produksi ubi kayu di Provinsi Lampung tahun 2017 mengikuti distribusi truncated normal. Dengan kata lain, rata-rata dari komponen inefisiensi teknis tidak sama dengan nol. Pengujian terhadap distribusi komponen inefisiensi teknis dapat dilihat pada Tabel 1.

Tabel 1. Uji Distribusi Komponan Inefisiensi Teknis

\begin{tabular}{llcrrl}
\hline Wilayah & Hipotesis & Log Likelihood & LR & Nilai Kritis & Keputusan \\
\hline Lampung & $H_{0}: \mu=0$ (Half Normal) & $-1723,1925$ & 16,6764 & 3,84 & Tolak Ho \\
& $H_{0}: \mu \neq 0$ (Truncated & $-1714,8543$ & & & \\
& Normal) & & & & \\
\hline
\end{tabular}

Sumber: Output FRONTIER 4.1 (diolah)

Sebelum melakukan analisis lebih lanjut mengenai karakteristik petani yang mempengaruhi inefsiensi teknis yang terjadi maka terlebih dahulu diuji apakah benar terdapat efek inefsiensi teknis dalam proses produksi. Dengan menggunakan bantuan aplikasi FRONTIER 4.1 hasil pengujian menunjukkan bahwa produksi ubi kayu di Provinsi Lampung tahun 2017 terdapat efek inefsiensi teknis dalam proses produksinya. Pengujian terhadap keberadaan efek inefisiensi teknis dapat dilihat pada Tabel 2.

Tabel 2. Uji Keberdaan Inefisiensi Teknis

\begin{tabular}{|c|c|c|c|c|}
\hline Wilayah & Hipotesis & LR & Nilai Kritis & Keputusan \\
\hline Lampung & $\begin{array}{l}\mathrm{H}_{0}: \gamma=0 \\
\text { (Tidak terdapat efek inefisiensi) } \\
\mathrm{H}_{0}: \gamma \neq 0 \\
\text { (Terdanat efek inefisiensi) }\end{array}$ & 16,6764 & 3,84 & Tolak $\mathrm{H}_{0}$ \\
\hline
\end{tabular}

Sumber: Output FRONTIER 4.1 (diolah)

Dalam melakukan perhitungan terhadap efisiensi teknis dilakukan juga estimasi terhadap parameter fungsi produksi ubi kayu ketika petani dalam kondisi efisien penuh dengan fungsi produksi Cobb Douglass. Hasil estimasi terhadap parameter fungsi produksi dapat dilihat pada Tabel 3. Variabel input yang berpengaruh signifikan terhadap output produksi ubi kayu di Provinsi Lampung tahun 2017 adalah luas panen dan bibit. Peningkatan 1 persen luas panen akan meningkatkan produksi ubi kayu sebesar 0,7308 persen. Sementara itu, peningkatan 1 persen bibit yang digunakan akan meningkatkan produksi sebesar 0,2547 persen. Lebih lanjut, hasil estimasi juga menampilan nilai gamma sebesar 0,8892 . Angka ini berarti 88,92 persen dari variasi error term disebabkan oleh 
komponen inefisiensi teknis. Setelah dilakukan estimasi terhadap parameter fungsi produksi cobbdouglas maka didapatkan rata-rata efisiensi teknis sebesar 0,76. Artinya, output yang dihasilkan masih 76 persen dari output maksimal yang seharusnya dapat dicapai, sisanya tidak tercapai karena permasalah inefisiensi yang tidak terkait langsung dalam teknis produksi ubi kayu. Menurut BPS, nilai efisiensi teknis tersebut berada pada kategori sedang.

Tabel 3. Estimasi Parameter Fungsi Produksi Cobb-Douglas

\begin{tabular}{|c|c|c|c|}
\hline \multirow{2}{*}{ Variabel } & \multicolumn{2}{|c|}{ Lampung } & \multirow[b]{2}{*}{ t-ratio } \\
\hline & Koefisien & Standard-error & \\
\hline Intercept & 1,7415 & 0,1034 & $16,8490 * *$ \\
\hline In luas panen & 0,7308 & 0,0242 & $30,1828 * *$ \\
\hline In bibit & 0,2547 & 0,0223 & $11,4327 * *$ \\
\hline In pupuk urea & $-0,0048$ & 0,0074 & $-0,6558$ \\
\hline In tenaga kerja & 0,0016 & 0,0070 & 0,2314 \\
\hline Gamma (४) & 0,8892 & 0,0300 & $29,8921^{* *}$ \\
\hline $\begin{array}{l}\text { Rata-rata } \\
\text { teknis }\end{array}$ & 0,76 & & \\
\hline
\end{tabular}

Sumber: Output FRONTIER 4.1 (diolah) Keterangan: ** Signifikan pada taraf nyata 5 persen

Hasil estimasi mengenai variabel karakteristik petani yang mempengaruhi inefisiensi teknis ditunjukan oleh Tabel 4. Variabel karakteristik petani yang mempengaruhi inefsiensi teknis produksi ubi kayu secara signifkan pada taraf alpha 5 persen diantaranya adalah jenis kelamin, tingkat pendidikan, dan keikutsertaan kelompok tani.

Tabel 4. Estimasi Parameter Inefsiensi Teknis

\begin{tabular}{|c|c|c|c|}
\hline \multirow{2}{*}{ Variabel } & \multicolumn{2}{|c|}{ Lampung } & \multirow[b]{2}{*}{ t-ratio } \\
\hline & Koefisien & Standard-error & \\
\hline Intercept & $-1,2066$ & 0,6880 & $-1,7539 *$ \\
\hline Jumlah ART & 0,0512 & 0,0469 & 1,0910 \\
\hline Jenis kelamin & 0,3588 & 0,1588 & $2,2600 * *$ \\
\hline Usia & 0,0055 & 0,0033 & $-1,6932 *$ \\
\hline Pendidikan & $-0,3355$ & 0,1295 & $-2,2590 * *$ \\
\hline Kepemilikan Lahan & 0,0351 & 0,0729 & 0,4809 \\
\hline Penyuluhan & 0,1964 & 0,1180 & 1,6646* \\
\hline Kelompok Tani & 0,1125 & 0,0564 & $1,9934 * *$ \\
\hline
\end{tabular}

Sumber: Output FRONTIER 4.1 (diolah) Keterangan: ** Signifikan pada taraf nyata 5 persen

*Signifikan pada taraf nyata 10 persen

Jenis kelamin petani berpengaruh signifikan terhadap inefsiensi produksi yang dihasilkan. Petani berjenis kelamin laki-laki di Provinsi Lampung memiliki nilai inefsiensi teknis 0,3588 lebih besar dibandingkan petani perempuan. Dengan kata lain petani laki-laki lebih tidak efisien dalam melakukan produksi dibandingkan petani perempuan. Hal tersebut berkebalikan dengan penelitian yang dilakukan oleh Taiwo et al. (2014) yang menyatakan petani laki-laki seharusnya lebih efisiensi daripada petani perempuan. Fenomena ini disebabkan pada tahun 2017 persentase petani perempuan yang menjadi kepala keluarga di Provinsi Lampung cukup tinggi yaitu sebesar 81,10 persen. Sehingga secara agregat petani perempuan mempunyai upaya yang lebih besar dalam menghasilkan ubi kayu dibandingkan petani laki-laki.

Berdasarkan Tabel 4, usia petani berpengaruh negatif signifikan terhadap inefisiensi teknis produksi ubi kayu. Penambahan satu tahun usia petani ubi kayu akan menurunkan nilai inefsiensi teknis sebesar 0,0055. Hal tersebut sejalan dengan penelitian Anggraini, Harianto dan Anggareni (2016) yang menyatakan semakin tua umur petani biasanya akan memiliki pengalaman yang lebih baik dalam bertani sehingga mampu meningkatkan efisiensi dalam menghasilkan ubi kayu. Dengan kata lain inefisiensi sebagai petani dalam menghasilkan ibu kayu semakin berkurang. Petani yang berusia lebih tua akan lebih baik dalam memberi keputusan karena memiliki lebih banyak pengalaman dalam berusaha tani dibandingkan petani yang berusia lebih muda (Sitanggang, 2018).

Sementara itu, petani ubi kayu yang telah menamatkan pendidikan minimal SLTP memiliki nilai inefsiensi teknis 0,3355 lebih rendah dibandingkan petani yang belum menamatkan pendidikan 
SLTP. Artinya, petani yang memiliki pendidikan rendah (belum menamatkan SLTP) lebih tidak efisien dalam melakukan produksi dibanding dengan petani yang memiliki pendidikan lebih tinggi (SLTP ke atas). Hal tersebut sesuai dengan penelitian Aboki et al. (2013) yang menyatakan bahwa lama pendidikan berpengaruh negatif dan signifikan terhadap inefsiensi produksi ubi kayu. Semakin tinggi pendidikan petani maka semakin mudah dalam menyerap informasi dan mengimplementasikan teknologi terbaru.

Petani ubi kayu di Provinsi Lampung yang mengikuti penyuluhan dan kelompok tani secara rata-rata memiliki inefisiensi teknis lebih tinggi dibandingkan petani yang tidak mengikuti penyuluhan dan kelompok tani. Petani yang mengikuti penyuluhan memiliki nilai inefisiensi 0,1964 lebih tinggi dibandingkan yang tidak ikut penyuluhan. Sementara itu, petani yang mengikuti kelompok tani memiliki nilai inefsiensi 0,1125 lebih tinggi dibandingkan yang tidak mengikuti kelompok tani. Hal ini berkebalikan dengan penelitian yang dilakukan oleh Taiwo et al. (2014) dimana keikutsertaan dalam penyuluhan dan kelompok tani seharusnya menurunkan inefisiensi teknis. Adeleke et al. (2008) menyebutkan bahwa keikutsertaan penyuluhan meningkatkan inefisiensi karena informasi yang disampaikan di penyuluhan tidak diterapkan oleh petani dalam kegitaan produksi. Sementara itu, inefsiensi keikutsertaan kelompok tani yang lebih tinggi mungkin disebabkan oleh ketidakaktifan para petani dalam kegiatan kelompok tani sehingga belum dapat memberi pengaruh besar dalam menurunkan inefisiensi teknis.

Di lain hal, jumlah ART dan status kepemilikan lahan di Provinsi Lampung berpengaruh terhadap inefisiensi namun pengaruhnya tidak signifikan. Secara singkat petani ubi kayu di Lampung yang memiliki nilai inefsiensi teknis lebih rendah memiliki karakteristik yaitu berjenis kelamin perempuan, berusia lebih tua, berpendidikan minimal SLTP, tidak mengikuti penyuluhan dan kelompok tani.

\section{KESIMPULAN}

Berdasarkan hasil penelitian dapat ditarik kesimpulan bahwa efisiensi teknis produksi ubi kayu yang dihasilkan Provinsi Lampung berada pada kategori sedang. Sementara itu, variabel karakteristik petani yang berpengaruh signifikan terhadap inefisiensi teknis adalah jenis kelamin petani, usia, pendidikan, keikutsertaan penyuluhan dan keikutsertaan kelompok tani.

Saran yang dapat diberikan berdasarkan kesimpulan yang telah didapatkan adalah pemerintah dapat melakukan sosialisasi terus menerus untuk menanamkan kesadaran mengenai pentingnya pendidikan, penyuluhan usahatani, dan keikutsertaan kelompok tani dalam meningkatkan produksi melalui peningkatan efisiensi teknis. Perbaikan dari sisi pengetahuan dan keterampilan petani dalam meningkatkan produktivitasnya lebih diutamakan untuk petani berjenis kelamin laki-laki, berusia muda, dan berpendidikan rendah. Pemerintah dapat meningkatkan kualitas manajerial petani melalui pendidikan nonformal dengan cara meningkatkan kuantitas maupun kualitas penyuluhan usaha tani. Pemerintah juga sebaiknya lebih memperhatikan kelompok tani sehingga keikutsertaan petani ubi kayu dapat menurunkan ineisiensi teknis produksi dalam bentuk subsidi pupuk urea maupun subsidi bibit unggul. Sebagian besar petani tinggal di daerah pedesaan dimana akses untuk berbagai fasilitas cukup sulit khususnya akses pendidikan. Oleh karena itu, pemerintah dapat membangun sekolah di daerah pedesaan ataupun membuka beberapa pelatihan keahlian nonformal mengingat pendidikan memegang perngaruh yang cukup tinggi dalam mengurangi inefsiensi produksi ubi kayu di Provinsi Lampung.

\section{DAFTAR PUSTAKA}

Aboki et al. (2013). Analysis of Technical, Economic and Allocative Efficiencies of Cassava Production in Taraba State, Nigeria. IOSR Journal of Agriculture and Veterinary Science, 5, 19-26.

Adeleke O.A. el. al. (2008). Application of Stochastic Production Frontier in the Estimation of Technical Effisiency of Cassava Farmers in Oluyole and Akinyele Local Government Areas of Oyo State. Journal of Agronomy 2, 71-77.

Aigner, D.J., Lovell, C.A.K, Schimdt, S.S. (1977). Formulation and Estimation of Stochastic Frontier Production Function Models. Journals of Econometric, 21-37.

Anggraini, A., Harianto, Anggraeni,L. (2016). Efisiensi Teknis, Alokatif, dan Ekonomi pada Usahatani Ubikayu 
di Kabupaten Lampung Tengah, Provinsi Lampung. Jurnal Agribisnis Indonesia, 4, 43-56.

Fried H.O., Lovell, C.A.K., Schmidt, S.S. (2008). The Measurement of Productive Efficiency and Productivity Growth. Oxford University Press.

Nainggolan, Kaman. (2011). Persoalan Pangan Global dan Dampaknya Terhadap Ketahanan Pangan Nasional. PANGAN, 20, 1-13.

Taiwo et al. (2014). Technical Efficiency Analysis of Cassava Production in Nigeria; Implication for Increased Productivity and Competitiveness. Journal of Agriculture and Enviromental Management, 3, 569-576.

Badan Pusat Statistik. (2015). Analisis Tematik ST213 Subsektor Estimasi Parameter dan Pemetaan Efisiensi Produksi Pangan di Indonesia. Jakarta: CV. Josevindo.

Coelli, et al. (2005). An Introduction to Efficiency and Productivity Analysis (2nded). Australia: Spinger Science+Business Media, Inc.

Kementerian Pertanian. (2016). Outlook Komoditas Pertanian Sub Sektor Tanaman Pangan. Jakarta: Pusat data dan Sistem Informasi Pertanian.

Kementerian Pertanian. (2015). Rencana Strategis Tahun 2015-2019. Jakarta: Deputi Bidang Koordinasi Pangan dan Pertanian.

Astuti, Siswi Puji. (2011). Analisis Impor Beras di Indonesia Periode 1980-2010[Skripsi]. Bogor: Institut Pertanian Bogor.

Rumapea, Romida. (2017). Analisis Efisiensi Teknis Usaha Tani Kedelai di Lima Provinsi Sentra Tahun 2014 (Stochastic Frontier Analysis) [Skripsi]. Jakarta: Sekolah Tinggi Ilmu Statistik.

Sitanggang, Yuni F. (2018). Analisis Efisiensi Teknis Usahatani CabaiMerah Keriting Menggunakan Stochastic frontier Analysis (SFA) di Desa Mojorejo Kecamatan Wates, Kabupaten Blitar [Skripsi]. Malang: Universitas Brawijaya.

Syafina, Lailan. (2014). Faktor-Faktor Yang MempengaruhiProduksiUbiKayu(StudiKasus: Desa Tandukan Raga, Kecamatan STM Hilir, kabupaten Deli Serdang). [Skripsi]. Medan: Universitas Sumatera Utara.

RI (Republik Indonesia). (2012). Undang-Undang No. 18 Tahun 2012 tentang Pangan. Lembaran Negara RI Tahun 2012, No. 227. Sekretariat Negara. Jakarta. 